\title{
Oversight of opioid advertising in Canada remains lax despite new federal guidance
}

\author{
口 Cite as: CMAJ 2018 June 11;190:E730-1. doi: 10.1503/cmaj.109-5612
}

Posted on cmajnews.com on May 24, 2018.

Y ears after drug advertising reviewers warned the federal government about lax controls over the promotion of prescription opioids, Health Canada issued a guidance to manufacturers indicating their ads may be subject to tougher scrutiny.

Meanwhile, some drug companies continue to promote prescription opioids with little or no review of whether their marketing claims downplay risks, according to Ray Chepesiuk, commissioner of the Pharmaceutical Advertising Advisory Board, which reviews ads in collaboration with Health Canada.

"There's the potential that a great amount of prescription opioid advertising material is not being reviewed," said Chepesiuk.

According to Chepesiuk, the only companies currently required to submit drug advertising claims for review are members of Innovative Medicines Canada, an industry association that represents brandname companies. But not all of Canada's drug companies are members of the industry association, Chepesiuk noted.

The advisory board, which charges fees to drug companies to review advertising materials, describes itself as "the only regulator whose preclearance service is recognized by Health Canada for advertising directed to health care professionals." It has long advocated for mandatory review of all opioid advertising in discussions with Health Canada, said Chepesiuk. "But it's up to Health Canada to drive this."

In email statements, Eric Morrissette, chief of media relations for Health Canada, said the department has issued a guidance that gives the government authority, on a case-by-case basis, to require manufacturers to submit their advertising for review by an advertising preclearance agency recognized by Health Canada, such as the Pharmaceutical Advertising Advisory Board.

The call for a larger mandate for the advertising advisory board was met with skepticism by Dr. Joel Lexchin, a drugpolicy researcher at the University of Toronto. According to Lexchin, there are serious weaknesses in the board's current approach, including a lack of requirement for equal space for harms and benefits in drug advertising.

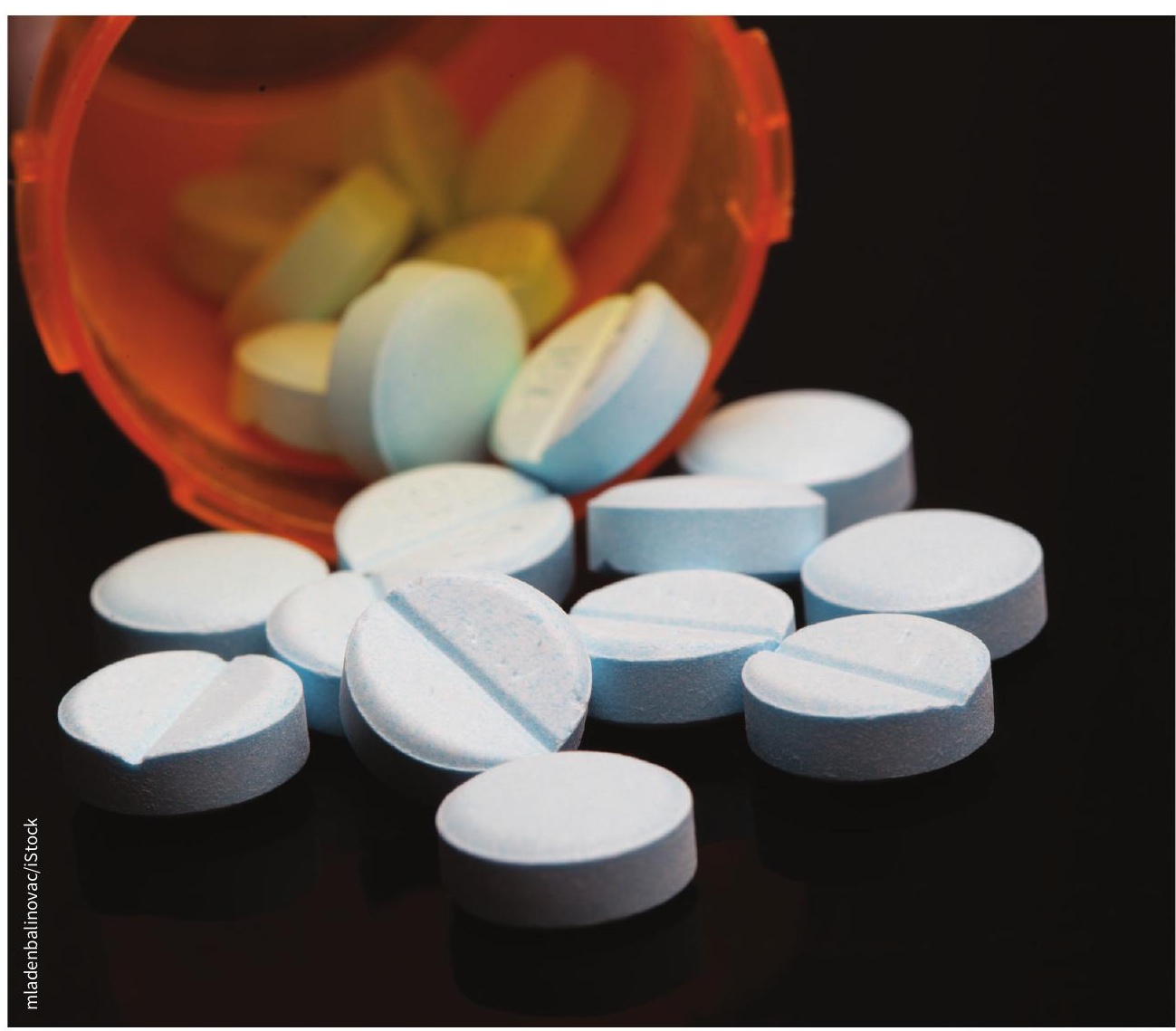

Drug companies continue to promote prescription opioids with little or no review of whether their marketing claims downplay risks, according to the Pharmaceutical Advertising Advisory Board.
The advisory board "approves ads that are clearly misleading, in my view," he said. Lexchin would like to see the board replaced by an entity entirely independent from industry that would conduct "independent, rigorous reviews of all forms of drug marketing."

Dr. Andrew Boozary, a University of Toronto internist who helped Lexchin launch Open Pharma, a group that advocates for independent review of drug advertising and full disclosure of corporate payments to health care professionals, 
said not enough is known about marketing tactics or payments to professionals.

"The opioid catastrophe vividly underlines our need for full transparency about payments to health care professionals and organizations," said Boozary.

Innovation Medicine Canada's code of conduct stipulates that members must ensure payments to professionals and organizations are "not undertaken for product promotional reasons" and "that there are no incentives to prescribe, recommend, purchase, supply or administer a product based on financial support."

The association "does not audit member companies to ensure compliance with the code," said Pamela Fralick, the group's president. "Stakeholders may also file complaints with Innovative Medicines Canada if they believe that a member-company is breaching the code."

Paul Webster, Toronto, Ont. 